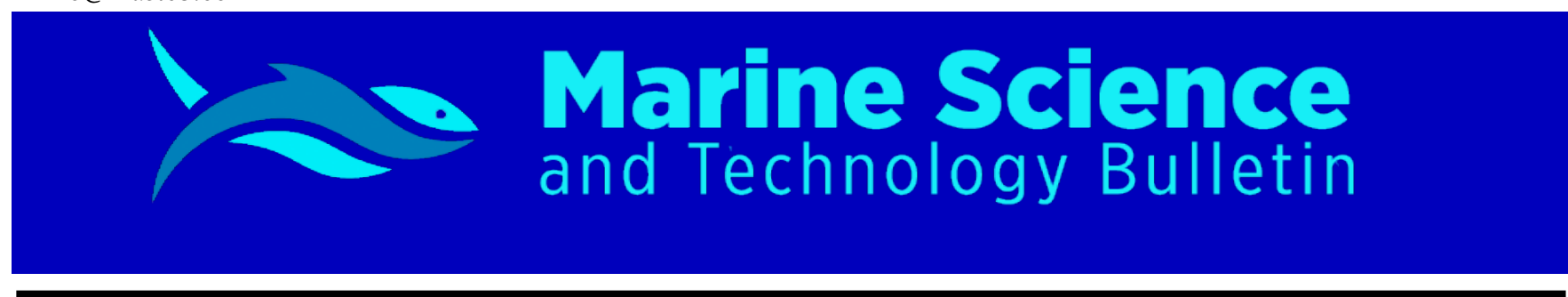

RESEARCH ARTICLE

\title{
First record of gravid female American blue crab (Callinectes sapidus Rathbun 1986) from the Black Sea
}

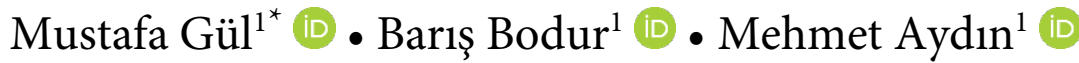 \\ ${ }^{1}$ Fatsa Faculty of Marine Science, Ordu University, Turkey
}

\begin{tabular}{l} 
A R T I C L E I N F O \\
\hline Article History: \\
Received: 16.09 .2020 \\
Received in revised form: 09.01 .2021 \\
Accepted: 15.01 .2021 \\
Available online: 26.01 .2021 \\
\hline
\end{tabular}

Keywords:
Black Sea
Blue crab
Callinectes sapidus
Gravid female
Mediterranization

\begin{abstract}
A B S T R A C T
The occurrence of American blue crab, Callinectes sapidus Rathbun 1896, has been reported from the Black Sea, however, no gravid female has previously observed. Here, we record the first gravid female blue crab from the Black Sea. One individual of Atlantic blue crab was caught at $2 \mathrm{~m}$ depth using trammel net on $24^{\text {th }}$ June 2020 . The carapace width, carapace length, and the wet body weight of the crab were $200 \mathrm{~mm}, 81.03 \mathrm{~mm}$, and 406.22 g, respectively. We also counted the eggs and measured the egg size. We further determined that the majority of the eggs were eyed, suggesting potential adaptation of the blue crabs to the Black Sea ecosystem.
\end{abstract}

Please cite this paper as follows:

Gül, M., Bodur, B., \& Aydın, M. (2021). First record of gravid female American blue crab (Callinectes sapidus Rathbun 1986) from the Black Sea. Marine Science and Technology Bulletin, 10(3), 224-227. https://doi.org/10.33714/masteb.795884

\section{Introduction}

Introductions of American blue crab have been reported from different localities on the coast of Europe including France, North Sea, Mediterranean Sea, Baltic Sea, Sea of Azov, and as well as Black Sea (Nehring, 2011). The species has reached a notable density in the Mediterranean and Aegean Seas (Holthuis \& Gottlieb, 1955; Williams, 1974; Castriota et al., 2012), however, its existence in the Black Sea has been rare (Bulgurkov, 1968; Shaverdashvili \& Ninua, 1975; Monin, 1984; Zaitsev, 1998; Bashtannyy et al., 2002; Diripasko et al., 2009; Khvorov, 2010; Pashkov et al., 2012; Aydın, 2017) (Figure 1), suggesting a low adaptation ability of the species to the low temperature values of the Black Sea (Nehring, 2011). This hypothesis might further be supported by the recent increase in the number of reports showing existence of the blue crabs from the Black Sea as the water temperature increases in the Black Sea during the "Mediterranization" process (Micu \& Todorova, 2009). Besides the reports showing the occurrence of the American blue crabs, no report has yet indicated reproductive capability of this species in the Black Sea including gravid females.

\footnotetext{
* Corresponding author

E-mail address: mustafaremzigul@odu.edu.tr (M. Gül)
} 


\section{Material and Methods}

We have collected a single gravid female of American blue crab from the mid of the Turkish coast of Black Sea (Figure 1). The individual was found at $2 \mathrm{~m}$ depth using a trammel net on $24^{\text {th }}$ June 2020 in the Fatsa port, Ordu $\left(41^{\circ} 02^{\prime} 45.81^{\prime \prime} \mathrm{N}\right.$ and $\left.37^{\circ} 29^{\prime} 31.83^{\prime \prime} \mathrm{E}\right)$. The individual was brought to the laboratory alive and was euthanized in ice. We then measured the carapace width and carapace length using a digital Vernier caliper to the nearest $0.01 \mathrm{~mm}$. We also measured the wet body weight of the crab. We collected three $1 \mathrm{~g}$ of subsamples from the clutch and counted the number of eggs. We finally measured the egg size (e.g. egg diameter) of 50 eyed eggs under a dissecting microscope.

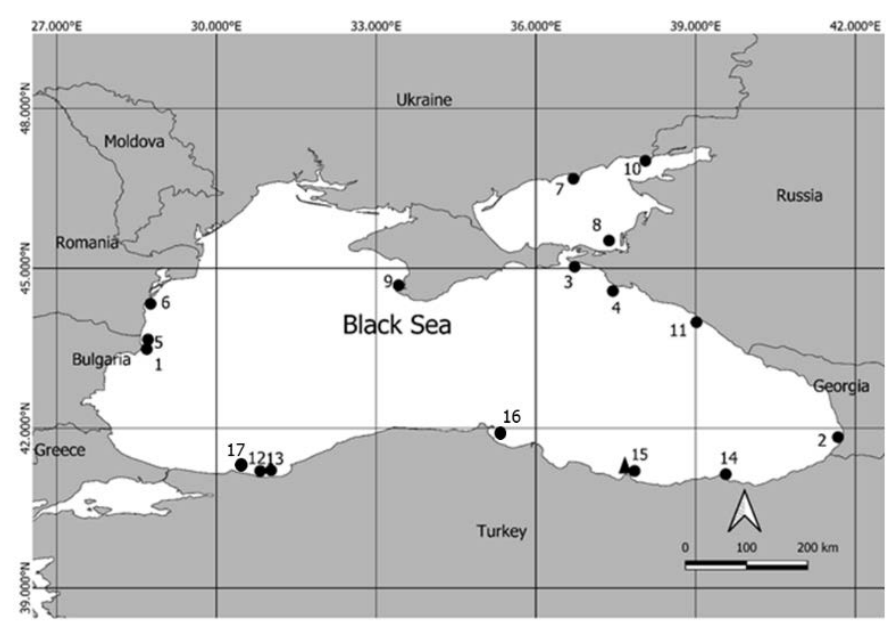

Figure 1. Map for the locations in the Black Sea where American blue crabs (Callinectes sapidus) have been reported. Locations are labeled chronologically from 1 to 15 . The triangle indicates the site for the present study. Bulgurkov $(1968)^{1}$, Shaverdashvili \& Ninua $(1975)^{2}$, Zaitsev (1998) 3$)^{3,5}$, Monin $(1984)^{4}$, Bashtannyy et al. $(2002)^{6}$, Diripasko et al. (2009) ${ }^{7,8,10}$, Khvorov $(2010)^{9}$, Pashkov et al. (2012) ${ }^{11}$, Yağlığlu et al. $(2014)^{12,13}$, Ak et al. $(2015)^{14}$, Aydin $(2017)^{15}$, Bilgin (2019) ${ }^{16}$, Ceylan $(2020)^{17}$.

\section{Results}

The carapace width (including the longest spines) and length of the crab was $200 \mathrm{~mm}$ and $81.03 \mathrm{~mm}$, respectively. The wet body weight was $406.22 \mathrm{~g}$ and the wet clutch weight was $33.84 \mathrm{~g}$. The female was carrying a total of 1166879 eggs. The majority of the eggs were eyed (Figure 2) and the diameter of the eyed eggs varied between $261.7 \mu \mathrm{m}$ and $309.5 \mu \mathrm{m}$ (average $=281 \pm 18.26 \mu \mathrm{m}$ ).

\section{Discussion}

This is the first record of a gravid female American blue crab in the Black Sea. Low water temperatures have been hypothesized to be the main causation for the unsuccessful establishment of the American blue crab in the Black Sea ecosystem (Nehring, 2011), since larval development and size at maturity are inversely related to the water temperatures (Hines et al., 2010) and no blue crab larvae can develop at water temperatures lower than $21^{\circ} \mathrm{C}$ (Hill et al., 1989). However, Black Sea ecosystem experiences strong consequences of the global changes, which is defined as the "Mediterranization" process, meaning that the Black Sea ecosystem is resembling to the Mediterranean character (Micu \& Todorova, 2009). This transformation in the Black Sea ecosystem has led to increase in water temperatures and the salinity, which overlaps with the increased number of records showing introduced species to the Black Sea including the American blue crab. Our finding here shows that the increased water temperatures of the Black Sea allow blue crab eggs to develop and allow females to carry eyed eggs and potentially release them, thought we do not have any information on the survival of the larvae.

Aquatic species are often transported to new localities unintentionally via ballast waters of the ships. However, the species itself or life form of the species must be small enough to pass through the ballast water pump and intake ports, thus the species that are carried in the ballast water are often limited to phyto- and zooplankton, and other planktonic larvae belonging to a variety of macroinvertebrates and fish (Minchin \& Gollasch, 2002). Therefore, it is reasonable to conclude that the gravid female that we collected was not transported to the Black Sea as an adult, and the coupling has happened in the Black Sea. Another potential explanation for the presence of the gravid female in the Black Sea was the migration of the blue crabs from

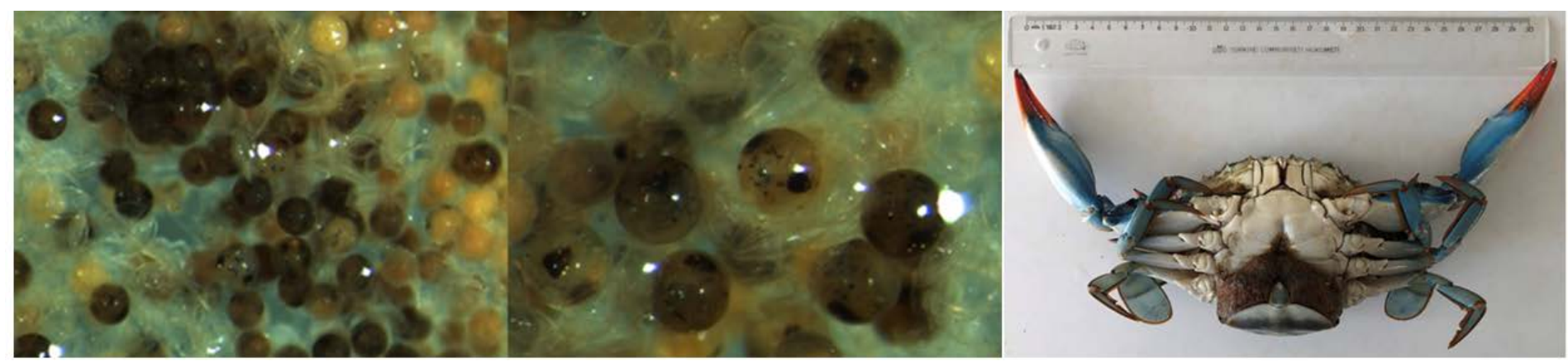

Figure 2. The views of the gravid female American blue crab (Callinectes sapidus) and the eyed eggs 
the Aegean Sea (Öztürk et al., 2020), suggesting that coupling might happen in the Aegean Sea and the female individual migrated to the Black Sea. If this is correct for the blue crabs from the Black Sea, the idea of eggs and potentially larvae development of the blue crabs in the Black Sea should be true. In conclusion, our finding here has shown that American blue crabs are able to reproduce and develop eggs in the Black Sea.

\section{Conclusion}

Individuals of American blue crab (Callinectes sapidus) have long been reported from different coastal areas of the Black Sea. However, there has been a doubt about whether the species has a durable settlement in the Black Sea due to the lack of evidence for the reproduction. Our finding here shows that American blue crab has adapted to the Black Sea system by gaining the ability of reproduction.

\section{Compliance with Ethical Standards}

\section{Conflict of Interest}

The authors declare that they have no conflict of interest.

\section{Ethical Approval}

For this study, all applicable international, national, and/or institutional guidelines for the care and use of animals were followed.

\section{References}

Ak, O., Haşimoğlu, A., \& Bayram, K. (2015). Southeastward expansion of the blue crab Callinectes sapidus (Rathbun, 1896) in the Black Sea. Cahiers de Biologie Marine, 56, 397-399. https://doi.org/10.21411/CBM.A.4A99282B

Aydın, M. (2017). First record of blue crab Callinectes sapidus (Rathbun 1896) from the Middle Black Sea coast. Turkish Journal of Maritime and Marine Sciences, 3(2), 121-124.

Bashtannyy, R., Webster, L., \& Raaymakers, S. (2002). 1st Black Sea Conference on Ballast Water Control and Management, Odessa, Ukraine, 10-12 October 2001: Conference Report. GloBallast Monograph Series No. 3. IMO London.

Bilgin, S. (2019). Review: An update list of crab species (Crustacea: Decapoda: Brachyura) with exotic crabs in the Black Sea fauna. Journal of Anatolian Environmental and Animal Sciences, 4(2), 211-215. https://doi.org/10.35229/jaes.566520

Bulgurkov, K. I. (1968). Callinectes sapidus Rathbun in the Black Sea. Izvest Niors, 9, 97-99.
Castriota, L., Andaloro, F., Costantini, R., \& De Ascentiis, A. (2012). First record of the Atlantic crab Callinectes sapidus Rathbun, 1896 (Crustacea: Brachyura: Portunidae) in Abruzzi waters, central Adriatic Sea. Acta Adriatica. 53(3), 467-471.

Ceylan, Y. (2020). The blue crab (Callinectes sapidus, Rathbun, $1896)$ is spreading in the southern coast of the Black Sea. Marine Science and Technology Bulletin, 9(2), 168-172. https://doi.org/10.33714/masteb.753593

Diripasko, O. A., Izergin, L. V., \& Koshkalda, A. I. (2009). First finds of the blue crab Callinectes sapidus (Portunidae, Decapoda) in the Sea of Azov. Vestnik Zoologii, 43(6), 529-532.

Hill, J., Fowler, D. L., \& Avyle, M. V. (1989). Species profiles: Life histories and environmental requirements of coastal fishes and invertebrates (Mid-Atlantic) - Blue crab. U.S. Fish Wildlife Service Biological Report. 82(11.100). U.S. Army Corps of Engineers, TR EL-82-4. 18 pp

Hines, A. H., Johnson, E. G., Darnell, M. Z., Rittschof, D., Miller, T. J., Bauer, L. J., Rodgers, P., \& Aguilar, R. (2010). Predicting effects of climate change on blue crabs in Chesapeake Bay. In: Kruse, G. H., Eckert, G. L., Foy, R. J., Lipcius, R. N., Sainte-Marie, B., Stram, D. L., \& Woodby, D. (Eds.), Biology and Management of Exploited Crab Populations under Climate Change. Alaska Sea Grant, University of Alaska Fairbanks. https://doi.org/10.4027/bmecpcc.2010.22

Holthuis, L. B., \& Gottlieb, E. (1955). The occurrence of the American blue crab, Callinectes sapidus Rathbun, in Israel waters. Bulletin of the Research Council of Israel, $5 B, 154-156$.

Khvorov, S. A. (2010). Decapods (Decapoda), in Vselentsy $v$ bioraznoobrazii i produktivnosti Azovskogo i Chernogo morei [Invaders in Biodiversity and Productivity of the Sea of Azov and Black Sea]. Matishov, G. G., \& Boltachev, A. R. (Eds.), (pp. 69-76.). YUNC RAN Publishing.

Micu, D., \& Todorova, V. (2009). Early signs of "mediterranization" and climate change in the Black Sea. In: Briand, F. (Ed.), Climate Forcing and Its Impacts on the Black Sea Marine Biota. No: 39 in CIESM Workshop Monographs, Monaco, 103-104.

Minchin, D., \& Gollasch, S. (2002). Vectors - How exotics get around. In: Leppäkoski, E., Gollasch, S., \& Olenin, S. (Eds.), Invasive aquatic species of Europe. Distribution, Impacts and Management. Kluwer Academic Publishers. 
Monin, V. L. (1984). New find of the blue crab Callinectes sapidus (Decapoda, Brachyura) in the Black Sea. Zoologicheskii Zhurnal, 63, 1100-1101.

Nehring, S. (2011). Invasion history and success of the American blue crab Callinectes sapidus in European and adjacent waters. In Galil, B. S., Clark, P. F., \& Carlton, J. T. (Eds.), In the Wrong Place - Alien Marine Crustaceans: Distribution, Biology and Impacts (pp. 607624). Invading Nature, Springer Series in Invasion Ecology 6, Springer.

Öztürk, R. Ç., Terzi, Y., Feyzioğlu, A. M., Şahin, A., \& Aydın, M. (2020). Genetic characterization of the invasive blue crab, Callinectes sapidus (Rathbun, 1896) in the Black Sea. Regional Studies in Marine Science, 39, 101412. https://doi.org/10.1016/j.rsma.2020.101412

Pashkov, A. N., Reshetnikov, S. I., \& Bondarev, K. B. (2012). The capture of the blue crab (Callinectes sapidus, Decapoda, Crustacea) in the Russian sector of the Black Sea. Russian Journal of Biological Invasions, 3(1), 22-28.
Shaverdashvili, R. S., \& Ninua, N. Sh. (1975). New find of crab Callinectes sapidus Rathbun, 1896 in the Black Sea. Nauchnye Doklady Vysshei Shkoly, 9, 19-20.

Williams, A. B. (1974). The swimming crabs of the genus Callinectes (Decapoda: Portunidae). Fishery Bulletin, 72(3), 685-798.

Yağlığlu, D., Turan, C., \& Öğreden, T. (2014). First record of blue crab Callinectes sapidus (Rathbun, 1896) (Crustacea, Brachyura, Portunidae) from the Turkish Black Sea coast. Journal of the Black Sea/Mediterranean Environment, 20, 13-17.

Zaitsev, Y. (1998). Samoe sinee v mire [Most Blue in the World]. New York: Izd. OON, 142 pp. 